DOI: 10.20472/IAC.2018.935.034

TEKLA NEMANISHVILI

Iv. Javakhishvili Tbilisi State University, Georgia

\title{
GEORGIAN EMIGRANTS' ONLINE SUPPORT GROUPS: EXPLORING SELF-PRESENTATION AND SOCIAL CAPITAL ON FACEBOOK
}

\begin{abstract}
:
There is a clear evidence that emigration is associated with negative psychological outcomes, such as acculturation stress, depression, suicidal feelings, etc. Emigrants use various strategies to solve the psychological problems. Being a member of emigrants' Facebook supportive groups is common among Georgians mostly living in Europe and North America. They use Facebook groups to get acquainted with other Georgian emigrants, share their ideas and important information, get social support from other members and cope with their everyday hassles. This study examines how Facebook group membership experience (frequency of activity and using self-presentation tactics) is associated with accumulating online social capital among Georgian emigrants. 105 Georgian emigrants from 15 Facebook groups participated in the online survey. The results showed that frequent checking of notifications, writing posts, comments, and likes on emigrants' Facebook groups are positively associated with both bridging and bonding social capital. In addition, strategic self-presentation on Facebook groups is also positively related to online social capital variables.
\end{abstract}

\section{Keywords:}

Facebook, online support groups, social capital, social support, self-presentation, emigrants, Georgian emigrants

JEL Classification: Z00, 131, J61 